\title{
Work health and safety and the criminal law in Australia
}

\author{
Richard Johnstone B Bus Sci LLB (Hons) PhD, Griffith University, Australia
}

\begin{abstract}
This paper analyses recent Australian debates about the use of the criminal law in work health and safety regulation. It argues that these debates have to be seen in the context of the historical development of work health and safety regulation in the United Kingdom and Australia. The first part of the paper shows that, since the late 19th century, contraventions against the Australian work health and safety statutes have not been regarded as 'really criminal', and have largely been addressed by informal measures and, since the 1980s, by administrative sanctions. When prosecutions have taken place, work health and safety issues have been individualised and decontextualised, so that defendants have been able to reduce their culpability in the eyes of the court. Significant legal barriers have undermined the use of the crime of gross negligence manslaughter against corporations and individuals. The second part of the paper analyses recent debates about restructuring gross negligence manslaughter and bolstering the 'criminality' of offences under the work health and safety statutes. It argues that the latter debate has been constrained by the historical forces examined in the first part of the paper, and that the current position, embodied in the recently harmonised Work Health and Safety Acts, favours attempting to recriminalise the work health and safety legislation. The debate about reforming gross negligence manslaughter has stalled.
\end{abstract}

\section{Key words}

Industrial manslaughter, corporate criminal liability, occupational safety and health, regulation

\section{Introduction}

Since late 2011, the Australian Commonwealth, states and territories have gradually been adopting a model Work Health and Safety Act endorsed by Australia's Workplace Relations Ministers' Council in 2009. This harmonisation of work health and safety law is the latest episode in 170 years of policy debate over the form and content of work health and safety regulation in Australia. In this paper I analyse the way in which the Australian debate over the past 25 years about the use of the criminal law in work health and safety has been shaped by deep-rooted historical processes, including the complexities surrounding the ambiguous form of the criminal law underpinning the work health and safety legislation.

Legislation regulating work health and safety in Australia dates back to 1854 for mining, when the colony of New South Wales enacted a short statute to regulate the inspection of coal mines, and to 1873 for industry generally, when Victoria enacted a Supervision of Workrooms and Factories Statute. Other colonies and, after Federation in 1901, states enacted their own work health and safety legislation, essentially adopting the UK Factories Acts of the time: Victoria in 1885; South Australia in 1894; New South Wales in 1896; Queensland in 1896; Western Australia in 1904; and Tasmania in 1910. These early work health and safety statutes, drawing heavily on the UK work health and safety regulatory models of the day, included sanctions for contraventions of some of the provisions in the statute, usually in the form of prosecution, potentially resulting in a pecuniary fine. 
In this paper I analyse the use of the criminal law in Australian work health and safety regulation and discuss recent policy debates aimed at strengthening the use of the criminal law in work health and safety enforcement, and reforming gross negligence manslaughter. A key aspect of my analysis is that current debates are strongly shaped by historical processes.

First, I argue that from the outset, and following the UK pattern, the mainstream work health and safety statutes have been 'decriminalised', in that work health and safety inspectorates have preferred to resort to informal approaches to enforcement (principally through advice and persuasion), and have initiated criminal prosecutions largely as a last resort. There has also been a strong tendency to regard the sanctions in the work health and safety statutes as not being 'really criminal'. This has been reinforced by a trend to prosecute mainly in response to incidents resulting in death or serious injury, so that offences have been 'individualised' and 'decontextualised' in a way that has enabled employers to reduce their culpability. I also suggest that work health and safety has been decriminalised in a second sense, in that the mainstream criminal law is generally not used to punish employers and managers highly culpable for workplace death and serious injury.

Second, I argue that these historical processes have framed and constrained recent attempts to bolster the criminality of work health and safety offences, and to reform the mainstream criminal law to facilitate manslaughter prosecutions where work-related deaths occur. I outline key features of the recent debate about the use of the criminal law in work health and safety regulation in Australia. From the late 1980s, this debate has had three foci. The first is on the possibility of making it easier to prosecute individuals, corporate employers and corporate officers for manslaughter under the mainstream criminal law. The second is on attempting to 'recriminalise' offences in the work health and safety statutes by increasing pecuniary penalties (fines). The third focus is on enhancing the 'criminality' of the work health and safety statutes themselves by creating new offences where contraventions of general duty provisions result in serious injury or death and/or involve criminal negligence or recklessness; and in introducing non-pecuniary penalties. I conclude that the latter two approaches have clearly prevailed, and have been institutionalised in the harmonised Work Health and Safety Acts.

\section{The decriminalisation of work health and safety offences in Australia}

\section{Hostages to history}

Historians have ably documented how, from the 1840s, the UK factory inspectorate's approach to enforcement focused on securing compliance through advice, persuasion and negotiation, rather than on prosecuting contraventions: prosecutions were used as a last resort, and reserved for 'serious' or 'wilful' offences. Carson ${ }^{1}$ has shown that this approach to enforcement was the inspectorate's way of responding to, and mediating, the conflicting social forces it faced at the time. On the one hand, there was strong support for 'effective regulation', not just from social movements agitating for better working conditions (such as the so-called Ten Hours Movement and its Shorter Time Committees) but also from upperand middle-class philanthropists, and from large, urban manufacturers who had, for various reasons, voluntarily improved factory conditions, and wanted to prevent being undercut by less scrupulous smaller employers and rural employers. On the other hand, the inspectors discovered that contravention of the Factory Acts was widespread, even among 'respectable' employers, and the heavy use of prosecution would have resulted in the 'collective criminalisation' of highly influential employers. The adoption of the 'advise and persuade' approach to enforcement institutionalised the 'ambiguity' of factory crime, so that despite it 
having the features of criminal law, it was not regarded as 'really criminal'; ${ }^{2}$ and were frequently breached and substantially tolerated in practice (that is, 'conventionalised'). ${ }^{3}$ These tendencies were reinforced by the fact that from 1844 the Factories Acts generally imposed strict liability (that is, did not require proof of intention to offend, or reckless or criminal negligence), and that health and safety offences have always largely been 'inchoate' (that is, contraventions can occur from unsafe conditions, even if no injury results). As Tombs $\&$ Whyte point out, both of these factors - strict or absolute liability, and the inchoate nature of work health and safety offences - further differentiate offences in the work health and safety statutes from 'real' crimes of violence in mainstream criminal law. ${ }^{4}$

Despite the fact that this differentiation of work health and safety crime from 'real' crime was socially constructed under particular historical circumstances, it was taken up elsewhere and has been widely accepted by researchers, regulators, lawyers and the community. It is clear that the early Australian inspectorates immediately adopted the 'advise and persuade' approach to work health and safety enforcement. For example, the Queensland inspectorate in 1896 sought to 'secure compliance with the provisions of the Act... without having to recommend stronger measures than persuasion'. ${ }^{5}$ In 1985, reflecting on his experience as Chief Inspector in Victoria from 1962 to 1973, Paul Prior suggested that: ${ }^{6}$

Most inspectorates... see as a failure any inspector who constantly has to launch prosecutions in order to obtain compliance. They see the legislation they administer as being remedial rather than punitive in nature, i.e. they are there to improve the conditions of work, not to make the employer or employee suffer penalties for breaches of the law.

Contemporary Australian work health and safety enforcement statistics show just how deeply entrenched this approach to enforcement is. Prosecution plays a very small part in the enforcement profiles of the current Australian work health and safety inspectorates. For example, the latest enforcement data across all Australian jurisdictions show that in 2010-11 there were 79,290 'proactive' workplace visits and 61,588 'reactive' workplace visits by inspectors in all jurisdictions around Australia. ${ }^{7}$ During these just over 140,000 visits, 1,101 inspectors issued 57,611 improvement, prohibition and infringement notices and completed 397 prosecutions, resulting in total fines of A\$15.5 million (an average fine of just over A $\$ 39,000) .{ }^{8}$ These data suggest that most enforcement action involves informal advice and persuasion, and when statutory enforcement sanctions are used by inspectors, they are principally improvement notices $(51,349)$. The number of prosecutions across all jurisdictions has been decreasing in recent years.

\section{Individualisation and decontextualisation of offences during prosecution}

I argue that work health and safety offences are 'decriminalised' in another sense: when prosecutions are taken, they focus on an incident resulting in serious injury or death, and in the process of prosecution that event is individualised and decontextualised, so that employer culpability is reduced, indeed sometimes trivialised. This conclusion was drawn from a study of 200 work health and safety prosecutions in Victoria in the magistrates' court in the period 1986 to 1998.* Even though the Australian work health and safety statutes provide for inchoate offences, the vast majority of work health and safety prosecutions focus on an 'event'. For example, in the Victorian study, 87 per cent of prosecutions were taken after a serious injury or fatality had occurred. ${ }^{10}$ Once the prosecution is focused on the incident

\footnotetext{
* For a comprehensive report on this research, see Johnstone. ${ }^{9}$
} 
causing the injury or fatality, the incident is easily drawn out of, or 'splintered' from, its broader context - the underlying system of work, the defendant's inadequate approach to systematic work health and safety management, production pressures and so on. ${ }^{11}$ One explanation for the low penalties imposed by courts for work health and safety offences (in the Victorian study the average fine was 20 per cent of the maximum penalty) has to do with the ease with which the defendant's representatives can use this event focus to decontextualise the offence and make it appear far less serious than it actually is when presenting arguments in mitigation of penalty. The defendant can focus the court's attention on the minute details of the event and use a number of very common arguments to further isolate the event from its work health and safety context. For example, in the Victorian study, the defence counsel regularly: ${ }^{12}$

- attempted to 'shift' blame onto the injured or deceased worker, a fellow worker, the supplier of the plant involved in the incident, or an inspector who had previously inspected the workplace without drawing attention to the hazard

- argued that the defendant was a 'good corporate citizen', with an unblemished record and good attitude to work health and safety - a submission that is very difficult to challenge because the prosecutor has a very limited role in the sentencing process, and usually had inadequate information about the defendant

- suggested that the event was a 'freak accident' or 'one-off' event, in the sense that the exceptional, the unforeseeable and hence the unpreventable had occurred

- tried to 'isolate the event in the past' by arguing that since the incident the defendant had introduced a new approach to managing health and safety, or a new management, so that the court had no cause to deter, rehabilitate or punish the defendant, because the wrong had been corrected.

Not only does this prosecution process trivialise work health and safety offences, and reduce the culpability of employers for providing unsafe working environments, but it also defuses work health and safety as an issue in capitalist economies. The court is seen to be dealing with work health and safety, and convicting offenders, but at the same time sanitising the issues so that work-related illness and injury are not seen as the result of poor work health and safety management and of unequal power structures, with the result that the underlying activity, the production of goods and services, is not threatened. In other words, the court plays a major legitimating role in work health and safety, but the underlying issues are largely untouched. Of course, to maintain legitimacy, the law must appear to be just and effective, and the few prosecutions that do take place play an important role in legitimising work health and safety regulatory regimes. ${ }^{13}$

I also argue that this approach is embedded in the form of the criminal law - which traditionally has focused on 'events' committed by 'individuals' with mens rea. For the criminal justice process to be used effectively to prosecute work health and safety offences, criminal law and procedure needs to be restructured to address crimes committed by organisations, where the egregious offence is a failure to take a systematic approach to work health and safety management in order to provide a working environment without work health and safety risks. ${ }^{14}$

\section{The Australian enforcement debate}

The renewed policy interest in work health and safety regulation in Australia has included a vibrant debate about enforcement, and ways of bolstering the sanctions in the work health and safety statutes. Since the late 1970s, each of the reformed Australian work health and 
safety statutes has provided work health and safety inspectors with the power to issue improvement and prohibition notices, and to launch prosecutions for contraventions of the work health and safety statutes. Prior to 2012, each of the Australian jurisdictions - apart from the Commonwealth, Victoria and Western Australia - had statutory provisions empowering inspectors to issue infringement notices (in South Australia, called an 'expiation notice') for at least some contraventions of the work health and safety statute. There were significant differences in the contraventions for which infringement notices (on-the-spot fines) could be issued, the persons to whom notices could be issued, and the amount of the fine (which ranged from A $\$ 315$ in South Australia to A \$1,500 in New South Wales). ${ }^{15}$

Another important development in most jurisdictions has been to enact provisions in the work health and safety statutes exposing senior officers in a corporation to criminal liability for failing to ensure that the corporation of which they were an officer complied with its work health and safety legal duties. Prior to 2012, most of the Australian work health and safety statutes attributed liability to directors and senior managers for the conduct of their company in certain circumstances. In some jurisdictions (Western Australia and Victoria prior to 2004), liability was 'accessorial', in the sense that officers were liable if the corporate offence was committed with their consent or connivance, or was due to their neglect. In other jurisdictions, liability was 'imputed' to senior officers. In New South Wales, Queensland and Tasmania, officers were deemed liable for the work health and safety offences of the corporation, unless they could establish a defence that they:

- were not in a position to influence the corporation (New South Wales and Queensland)

- had no knowledge of the offence (Tasmania)

- were in such a position (or had the requisite knowledge) but had exercised all due diligence to ensure that the corporation met its duties.

In Victoria, South Australia, the Northern Territory and the Australian Capital Territory (ACT), officers were made personally liable if the contravention of their company was attributable to the officer failing to take reasonable care. Only in Queensland and the Northern Territory could officers be imprisoned for contravening the officers' duty. The possibility of imprisonment certainly helps assert the criminality of the work health and safety statutes; but very low prosecution rates 'conventionalised' these offences. *

From 2012, the jurisdictions adopting the model Work Health and Safety Act (as part of a process to harmonise work health and safety statutes $)^{\dagger}$ have enacted a positive and proactive duty requiring officers to exercise due diligence to ensure that the person conducting the business or undertaking complies with its duties and obligations under the Act. Where an officer is reckless and engages in conduct that exposes an individual to whom a duty is owed to a risk of death or serious injury or illness, the officer can be imprisoned for up to five years.

Before 2012, five Australia work health and safety statutes (the Commonwealth, Victoria, Queensland, Tasmania and the ACT) gave work health and safety inspectorates the power to accept enforceable undertakings 'offered' by an individual or firm allegedly in breach of the

* See further, Johnstone $\&$ Tooma. ${ }^{16}$

${ }^{\dagger}$ For an overview of harmonisation, see Johnstone \& Tooma's Work health and safety regulation, and chapter 3 for a discussion of the officer's duty in the model Act. ${ }^{17}$ 
health and safety statute. The individual or firm makes a promise to the regulator to do or refrain from doing certain activities. If contravened, the undertaking is enforceable in court, often with additional penalties for the contravention of the undertaking. * Enforceable undertakings are included in the harmonised Work Health and Safety Acts.

Four other initiatives have been taken in recent years to, in some way, address the issue of 'the criminality' of work health and safety contraventions. These include:

- attempts at reforms to make it possible to successfully prosecute corporations and officers and/or senior managers for gross negligence manslaughter

- imposing higher levels of fines for contraventions of the work health and safety statutes

- creating new offences with additional elements, such as mens rea and/or serious injury/fatality

- giving courts a wider range of sanctions, such as court-ordered publicity, modified community service orders, and corporate probation.

The remainder of this paper will critically evaluate these four initiatives and, in particular, will examine the way in which they address the historical process of decriminalising work health and safety offences.

Manslaughter

Earlier in this paper, I argued that contraventions of work health and safety statutes have been 'decriminalised' in two senses. There is, of course, a third and more obvious sense in which work health and safety contraventions have been 'decriminalised', and that is in the failure of the 'mainstream' criminal law to develop rules to ensure that corporations and corporate officers can be prosecuted for manslaughter when there is a fatality at work.

From the mid-1980s, the revived Australian public policy interest in work health and safety regulation included a strong debate about the possibility of prosecuting corporations and senior officers responsible for workplace fatalities with charges of manslaughter and other mainstream criminal law crimes. The debate about possible 'industrial manslaughter' prosecutions was partly a response to some major incidents involving multiple work fatalities, for example the explosion in 1986 at the Laverton North (in the state of Victoria) foundry of Simsmetal Limited, which killed four workers and injured another seven.

The crime most likely to be used to prosecute employers responsible for work-related deaths is manslaughter by gross or criminal negligence, which involves: ${ }^{19}$

... 'a great falling short of the standard of care' which a reasonable person would have exercised, involving 'such high risk that death or grievous bodily harm would follow that the doing of the act merited criminal punishment'.

Note that there is no reason why gross negligence manslaughter should only apply when an employee is killed as a result of an employer's gross negligence - gross negligence manslaughter can be committed by an employer where its gross negligence causes the death of non-employees, including members of the public.

\footnotetext{
* See Johnstone $\&$ King. ${ }^{18}$
} 
To date, there have only been a few attempts at prosecuting firms or senior managers for manslaughter for workplace death, and I am only aware of three successful prosecutions. In Queensland in the 1990s, in $R v$ O'Connor, a director of a small company was convicted and imprisoned for 18 months - other details of the case are difficult to come by. In 2008, the operator of a small business and an employee were convicted of manslaughter by criminal negligence, after both entered a guilty plea. The District Court of New South Wales considered that both parties had a low level of culpability, and sentenced the owner of the business to a two-year suspended sentence, and the charge against the employee was dismissed without recording a conviction. ${ }^{20}$

In principle, there is no reason why a corporation, corporate officer or manager could not be prosecuted under this existing law. ${ }^{21}$ To date, there has only been one successful Australian prosecution of a corporation for gross negligence manslaughter: $R v$ Denbo Pty Ltd (1994), ${ }^{22}$ where a small company entered a guilty plea after a truck driver was killed when the truck's brakes failed while taking a steep short-cut on a construction site. The evidence suggested that one director knew the brakes were faulty and should have had them fixed or instructed the worker to take another route.

Why are prosecutions for gross negligence manslaughter so rare? One explanation is that whenever there is a fatality at work, the police defer to the work health and safety inspectorate, who conduct investigations and prosecute, if at all, for contraventions of the relevant work health and safety statute. Work health and safety regulators are, however, aware of the possibility of referring the matter to the police or the relevant Director of Public Prosecutions for a manslaughter prosecution, but this is rarely done, because of the difficulties of proving that a corporation, or a corporate officer, committed the offence.

\section{Corporate manslaughter}

The major difficulty in launching manslaughter prosecutions against corporations is that Australian corporate criminal liability for manslaughter is based on direct liability, and 'it must be shown that an act or omission was performed by someone with the authority to act as the corporation'. ${ }^{23}$ In corporate manslaughter cases, Australian courts have generally followed the attribution principle set out in Tesco Supermarkets Ltd $v$ Natrass [1972] AC 153, where the UK House of Lords in effect held that the only persons whose state of mind and conduct can be attributed to the company are the board of directors, the managing director, or any other person to whom a function of the board has been fully delegated. Thus, in $R v A$ C Hatrick Chemicals Pty Ltd (1995) 140 IR 243, Hampel J held (at 254) that neither the plant engineer nor the plant manager and safety co-ordinator, or the two employees who were alleged to have acted with gross negligence, 'were acting as the Company'. Rather, their 'acts were personal failures to act so as to give effect to the will of the company'. This principle has been heavily criticised as failing to reflect the principle of corporate blameworthiness, and being unworkable in the context of larger organisations. *

There have been three attempts to reform this attribution principle in Australian law. The first is to be found in Part 2.5 of the Criminal Code Act 1995 (Cth), which has the potential significantly to alter the Australian law of corporate criminal responsibility.

\footnotetext{
* See Fisse. ${ }^{24}$
} 
Section 12.3 provides that:

(1) If intention, knowledge or recklessness is a fault element in relation to a physical element of an offence, that fault element must be attributed to a body corporate that expressly, tacitly or impliedly authorised or permitted the commission of the offence.

Sub-section (2) provides further details of 'the means by which such an authorisation or permission may be established', which include:

(a) proving that the body corporate's board of directors intentionally, knowingly or recklessly carried out the relevant conduct, or expressly, tacitly or impliedly authorised or permitted the commission of the offence; or

(b) proving that a high managerial agent of the body corporate intentionally, knowingly or recklessly engaged in the relevant conduct, or expressly, tacitly or impliedly authorised or permitted the commission of the offence; or

(c) proving that a corporate culture existed within the body corporate that directed, encouraged, tolerated or led to non-compliance with the relevant provision; or

(d) proving that the body corporate failed to create and maintain a corporate culture that required compliance with the relevant provision.

'Corporate culture' is defined in section $12.3(6)$ as:"

... an attitude, policy, rule, course of conduct or practice existing within the body corporate generally or in the part of the body corporate in which the relevant activities takes place.

Offences such as manslaughter by gross negligence are dealt with by section 12.4 , which provides that:

(2) If

(a) negligence is a fault element in relation to a physical element of an offence; and

(b) no individual employee, agent or officer of the body corporate has that fault element; that fault element may exist on the part of the body corporate if the body corporate's conduct is negligent when viewed as a whole (that is, by aggregating the conduct of any number of its employees, agents or officers).

(3) Negligence may be evidenced by the fact that the prohibited conduct was substantially attributable to:

(a) individual corporate management, control or supervision of the conduct of one or more of its employees, agents or officers; or

(b) failure to provide adequate systems for conveying relevant information to relevant persons in the body corporate.

In short, these provisions enable proof of gross negligence to be established by examining the combined conduct of employees, officers and agents, rather than just the conduct of a very senior officer.

In practice, however, this important reform has had virtually no impact, for two reasons.

* See further, section 2(4) for factors relevant to paragraphs (2)(c) and (d). 
First, there is no crime of industrial manslaughter in the Commonwealth Crimes Act. Second, only one other Australian jurisdiction has enacted these Commonwealth provisions - the ACT, in sections 51 (fault elements other than negligence) and 52 (negligence) of the Criminal Code 2002 (ACT), but only for crimes enacted after 2002. The ACT government has, in fact, enacted a new crime of industrial manslaughter, and this will be examined later in this paper. In a 2000 discussion paper, the Queensland Department of Justice and Attorney-General recommended that the Queensland parliament adopt the Commonwealth Criminal Code Act provisions, but this proposal was shelved late in 2002.

The second reform initiative was in Victoria, in the form of the Victorian Crimes (Workplace Deaths and Serious Injuries) Bill 2001, which also contained an aggregation principle, albeit in a slightly different form. It allowed for 'the conduct of the body corporate as a whole to be considered' (clause $14 \mathrm{~B}(4)$ ) and provided (clause $14 \mathrm{~A}(2)$ ) that the conduct of an employee, agent or senior officer of a body corporate acting within the actual scope of their employment, or within the actual authority, 'be attributed to the body corporate'. This meant that 'the conduct of any number of employees, agents or senior officers of the body corporate may be aggregated' (clause 14B(5)), except that the negligence of an agent 'in the provision of services' could be taken into consideration but may not be attributed to the corporation (clause $14 \mathrm{~B}(5)$ (b)).

Clause $14 \mathrm{~B}(6)$ of the Victorian Bill then provided that the:

... negligence of a body corporate may be evidenced by the failure of the body corporate:

a) adequately to manage, control or supervise the conduct of one or more of its employees, agents or senior officers; or

b) to engage as an agent a person reasonably capable of providing contracted services; or

c) to provide adequate systems for conveying relevant information to relevant persons in the body corporate; or

d) to take reasonable action to remedy a dangerous situation of which a senior officer has actual knowledge; or

e) to take reasonable action to remedy a dangerous situation identified in a written notice served on the body corporate by or under an Act.

The Bill was innovative for another reason - it proposed two new crimes: 'corporate manslaughter', which involved 'a corporate body which by negligence kills a worker in the course of the worker's employment' (clause 13); and 'negligently causing serious injury by a body corporate' (clause 14). For the purposes of these two offences, conduct is 'negligent' (clauses $14 \mathrm{~B}(1)$ and $(2))$ if it:

... involves such a great falling short of the standard of care that a reasonable body corporate would exercise in the circumstances and such a high risk of death or really serious injury [or high risk of serious injury] that the conduct merits criminal punishment.

In determining whether a body corporate was negligent, 'the relevant duty of care is that owed by a body corporate to the person killed or seriously injured' (clause $14 \mathrm{~B}(3)$ ). In short, the elements of the corporate manslaughter offence codified the common law test for 'gross negligence' manslaughter.

After strong public opposition, particularly from employers, the Bill was abandoned in 2002. 
Prosecuting corporate officers for manslaughter

Two legal obstacles make it difficult for corporate officers to be prosecuted for manslaughter. The first is that to succeed in a manslaughter prosecution, the prosecutor must show that the director owed a 'civil law duty of care' to the deceased that was grossly breached, and that the breach caused the death; the second is that the prosecutor must prove that an 'act' of the officer caused the death. ${ }^{25}$

The first obstacle arises because in most cases it is the company (not an officer) that has a duty towards employees and others. In other words, in most cases the officer does not owe a civil law duty of care to employees - the officer's duty is to the company. There are exceptions to this rule where the officer personally 'procured, directed or authorised' the company to commit the unlawful act in question which resulted in the harm; and where the officer had acted in such a way towards the deceased that the officer had 'assumed' a personal responsibility towards the injured person so as to create between them 'a special relationship'. ${ }^{26}$

The second obstacle arises because an omission or failure to act is not an 'act', and will not establish criminal liability for a death or serious bodily injury under common law, unless 'the law imposes a duty to act' ${ }^{27}$ In most cases where it is alleged that an officer should be liable for manslaughter, the allegations tend to focus on an omission by the officer.

Both the Victorian and ACT reforms discussed above also addressed manslaughter by officers. The Victorian Bill attempted to build the liability of 'senior officers' onto the corporate offences. Clauses $14 \mathrm{C}(1)$ and (2) provided that if it was proven that the body corporate committed the crimes of corporate manslaughter or of negligently causing serious injury, a senior officer of the body corporate could also be found liable for an indictable offence (accessorial liability). These crimes would be committed if:

(a)(i) the senior officer was 'organisationally responsible' for the conduct, or part of the conduct, of the corporation in relation to the commission of the offence by the corporation (see also clauses $14 \mathrm{D}(3)(\mathrm{a})-(\mathrm{c})$ );

(ii) in performing or failing to perform her or his organisational responsibilities, the officer 'contributed materially' to the commission of the offence;

(iii) the officer knew, as a consequence of her conduct, that there was a substantial risk that the body corporate would engage in conduct that involved a high risk of death or really serious injury; and

(b) having regard to the circumstances known to the senior officer, it was unjustifiable to allow the substantial risk to exist. Senior officers acting without any fee, gain or reward could not be liable for these offences.

The third reform initiative was in 2003, when the ACT parliament enacted the Crimes (Industrial Manslaughter) Amendment Act 2003, which created new offences of 'industrial manslaughter'. Sections 49C and 49D provided that 'employers' (defined very broadly and including government and corporate employers) and 'senior officers' (defined in s 49A) may be charged with the offence of industrial manslaughter if a 'worker' employed or engaged by the employer:

(i) dies in the course of employment or while providing services to the employer;

(ii) the employer or senior officer's conduct causes the death; and

(iii) the employer or senior officer is

(a) reckless about causing harm to the employer or any other worker of the employer; or

(b) negligent about causing the death of the worker, or any other worker of the employer. 
'Conduct' is defined to include omissions to perform a duty to avoid or prevent danger to the life, safety or health of a worker if the danger arises from an act of the employer or officer, anything in the employer's or officer's possession or control, or any undertaking of the employer or officer.

Note that employers and senior officers can only commit manslaughter under these provisions in relation to a 'worker', who is defined to include 'employees', 'independent contractors', 'outworkers', 'apprentices', 'trainees' and 'volunteers'. This excludes fatalities caused to members of the public and persons who are not covered by the broad definition of 'worker'.

The Act provides for substantial penalties where the offence of industrial manslaughter has been committed. The maximum penalty is $\mathrm{A} \$ 200,000$ and/or imprisonment for 20 years. The court can order corporations to take actions including publicising the offence, notifying specified persons of the offence, or carrying out a specified project in the public interest, although the total cost to the defendant of carrying out these orders and paying fines cannot exceed A $\$ 5,000,000$.

\section{Complexities}

At the end of 2012, despite much debate over the potential use of industrial manslaughter prosecutions in Australia, only in the ACT has legislation been enacted to allow the acts of employees, officers and agents of a corporation to be aggregated to determine whether a corporation has been reckless or grossly or criminally negligent in causing the death of a worker, and to provide for the possibility of officers being prosecuted for recklessly or grossly negligently causing the death of a worker. The ACT is a very small jurisdiction, with just over 195,000 employees, a third of whom are employed in public administration. About a third are employed in professional, scientific and technical services, education and training, health care and social assistance. Most of the other employees are employed in retail and in other service industries. Just over 10 per cent of employees work in construction, manufacturing and transport, postal and warehousing. In other words, the ACT is not home to many dangerous occupations, although late in 2012 an inquiry into safety in the ACT's construction industry reported on the poor levels of compliance in that industry.

There are other complex strands in the Australian manslaughter debate. Australian courts have repeatedly made it clear that the primary purpose of work health and safety prosecutions is deterrence - both general and specific. Some advocates of manslaughter prosecutions assume that these prosecutions will also have a deterrent effect, but respected commentators $^{28}$ have argued that there is little evidence that manslaughter prosecutions will have a deterrent effect, and that manslaughter prosecutions should be used for symbolic purposes. Indeed, it would make more sense for regulators to see manslaughter prosecutions as retributive and symbolic, and primarily concerned with reaffirming society's abhorrence of work deaths.

Other writers ${ }^{29}$ have argued that manslaughter prosecutions are complex because by focusing on a few particularly serious cases and singling them out for 'special treatment', the regulator risks further undermining the 'criminality' of work health and safety offences. In other words, unless their purpose is clear, the use of manslaughter prosecutions could be reinforcing that work health and safety prosecutions are not 'really criminal' because when there is a serious fatality, the 'real' criminal law is used. 
Digression: harassment and Brodie's law

In 2006, a young café employee, Brodie Panlock, jumped off a building to her death following persistent and systematic physical and emotional bullying at work. In 2010, WorkSafe Victoria brought a number of successful prosecutions under the general duty provisions of the Occupational Health and Safety Act 2004 (Vic) against four employees (including managerial employees) working in the café.

The case spawned a debate about the use of anti-stalking provisions in each of the Australian criminal codes, which proscribe behaviour calculated to harass, threaten or intimidate other persons. In 2012, the Victorian government enacted the Crimes Law Amendment Act 2011 (Vic), which amended s 21A of the Crimes Act 1958 (Vic) to ensure that the crime of stalking (which could lead to imprisonment for up to 10 years) included:

(da) making threats to the victim;

(db) using abusive or offensive words to or in the presence of the victim;

(dc) performing abusive or offensive acts in the presence of the victim;

(dd) directing abusive or offensive acts towards the victim; ...

(g) acting in any other way that could reasonably be expected -

(i) to cause physical or mental harm to the victim, including self-harm; or

(ii) to arouse apprehension or fear in the victim for his or her own safety or that of any other person - with the intention of causing physical or mental harm to the victim, including self-harm, or of arousing apprehension or fear in the victim for his or her own safety or that of any other person.

In November 2012, a Commonwealth parliamentary inquiry into workplace bullying declined to recommend that a national equivalent of this legislation be enacted, and instead called for a national advisory service to assist employers and workers deal with the issue.

\section{Strengthening the criminality of the work health and safety offences}

Some writers argue that there is another way - apart from using the mainstream criminal law - of reasserting the criminality of work health and safety offences, and that is to take measures to reclaim and strengthen the criminality of contraventions of existing work health and safety statutes.

For example, in the debate about industrial manslaughter in the United Kingdom, Appleby ${ }^{30}$ argued that rather than introduce new provisions for industrial manslaughter, work health and safety would be better served if regulators were to 'rehabilitate the status' of the Health and Safety at Work etc Act 1974 (UK) for many industrial deaths by emphasising that its breach is truly 'criminal', as work health and safety law is in fact criminal law. The Australian National Review into Model Occupational Health and Safety Laws was careful to emphasise that contraventions of the work health and safety statues, and in particular the general duty provisions, were, and should be, 'criminal'. It noted that: ${ }^{31}$

Providing for a breach of a duty of care to be a criminal offence is an essential element of modern OHS legislation, and is consistent with the graduated approach to securing compliance with the laws. Broadly put, it reflects the community's view that any person who has a workrelated duty of care but does not observe it should be liable to a sanction for placing another person's health and safety at risk. Such an approach is also in line with international norms... Making non-compliance with a duty of care a criminal offence not only reflects the seriousness with which such conduct is regarded, but also reinforces the provision's deterrent effect. 
Addressing the suggestion from some quarters that work health and safety offences were 'quasi criminal', the National Review Panel said that: ${ }^{31}$

Our attention has been drawn to a risk that contraventions of OHS laws may be perceived as not being 'real' offences, even though there should be no doubt that they are precisely that.

Indeed, a key policy approach in Australia since the early 1980s has been to increase the maximum fines for work health and safety offences. This approach has been intensified over the past decade.

\section{Ratcheting up penalties for breach of existing duties}

At the end of the 1970s, the maximum fine in many of the Australian work health and safety statutes was in the region of A $\$ 2,000$. During the wave of reforms influenced by the UK Robens Report and the UK Health and Safety at Work etc Act 1974, the maximum fines were increased markedly in some statutes - for example, the maximum fines for a corporation for breach of a general duty provision in the Occupational Health and Safety Act 1985 (Vic) was A \$40,000, and A\$50,000 for four 'serious offences', which included failing to comply with a prohibition notice; obstructing, assaulting or intimidating an inspector; wilful repetition of an offence; and discrimination against employees or prospective employees who raised work health and safety issues or exercised functions under the Act. In 1990, the maximum fines for corporations for 'serious offences' was increased to $\mathrm{A} \$ 250,000$, and from 1998 the maximum fine for corporations for indictable offences (including the general duty provisions) was increased to $\mathrm{A} \$ 250,000$ if prosecuted in the County Court. Then in 2005, when the 1985 Act was replaced by the Occupational Health and Safety Act 2004 (Vic), the maximum fine for corporations was increased to A $\$ 1,020,780$. The maximum penalties in each of the other Australian work health and safety statutes were also increased significantly. Thus, by the end of 2011, the maximum fine for corporations in New South Wales was A\$550,000 (A \$825,000 for repeat offences); in Western Australia A $\$ 500,000$ (A $\$ 625,000$ for repeat offences); in South Australia A $\$ 300,000$; in Tasmania A $\$ 150,000$; in the ACT A $\$ 200,000$; and in the Northern Territory $\mathrm{A} \$ 550,000$.

High maximum penalties are, of course, of little point if the actual fines imposed by the courts are small, and if defendants can individualise and decontextualise offences as described earlier in this paper. In recent times the Australian courts have developed a series of sentencing principles for work health and safety offences, which go some way to addressing these two concerns. The key principles recently were summarised in a series of federal court decisions: ${ }^{32}$

- The penalty must be such as to compel attention to occupational safety and health generally, to ensure that workers while at work will not be exposed to risks to their health and safety.

- It is a significant aggravating factor that the risk of injury was foreseeable, even if the precise cause or circumstances of exposure to the risk were not foreseeable.

- The offence may be further aggravated if the risk of injury is not only foreseeable but actually foreseen, and an adequate response to that risk is not taken by the employer.

- The gravity of the consequences of an accident does not of itself dictate the seriousness of the offence or the amount of penalty. However, the occurrence of death or serious injury may manifest the degree of the seriousness of the relevant detriment to safety. 
- A systemic failure by an employer to appropriately address a known or foreseeable risk is likely to be viewed more seriously than a risk to which an employee was exposed because of a combination of inadvertence on the part of an employee and a momentary lapse of supervision.

- General deterrence and specific deterrence are particularly relevant factors in light of the objects and terms of the Act.

- Employers are required to take all practicable precautions to ensure safety in the workplace. This implies constant vigilance. Employers must adopt an approach to safety which is proactive and not merely reactive. In view of the scope of those obligations, in most cases it will be necessary to have regard to the need to encourage a sufficient level of diligence by the employer in the future. This is particularly so where the employer conducts a large enterprise which involves inherent risks to safety.

- Regard should be had to the levels of maximum penalty set by the legislature as indicative of the seriousness of the breach under consideration.

- The neglect of simple, well-known precautions to deal with an evident and great risk of injury, take a matter towards the worst case category.

- The objective seriousness of the offence, without more may call for the imposition of a very substantial penalty to vindicate the social and industrial policies of the legislation and its regime of penalties.

While these principles clearly indicate that work health and safety offences are to be regarded as very serious, and that duty holders are required to take a systematic approach to eliminating and controlling work health and safety risks, the principles do not explicitly address the 'isolation techniques' discussed earlier in this chapter, so there is still ample opportunity for defence counsel to seek to individualise and decontextualise offences during the sentencing process. The fifth principle, in fact, might encourage defendants to shift blame onto workers, and there is little to prevent defendants isolating the incident in the past.

\section{Higher fines where there is mens rea and/or fatality or serious injury}

Another key development, particularly during the past decade, was the introduction in a number of the work health and safety statutes of provisions imposing higher maximum penalties where an incident resulted in death, serious injury or a serious risk of death or serious injury, and where there was an element of mental intention (mens rea). This approach seeks to reduce the extent to which health and safety offences are differentiated from 'real' crimes of violence, by linking the offence more directly with the violent outcome of the contravention, and by the element of mens rea, a distinctive aspect of 'real' crime. Increasing the fine where a fatality results is, of course, not a new policy response. The UK Factories Amendment Act 1844, the first Factory Act to regulate machinery safety, imposed maximum fines of $£ 20$ for breach of the Act; but increased this to $£ 100$ for breaches of the safety provisions that resulted in injury or death. This sort of provision, and the additional element of mens rea, was largely absent from the Australian work health and safety statutes enacted in the late 1970s and early 1980s, but has re-emerged in the past decade.

Some of the statutes only provided for higher fines for contraventions resulting in injury or death. For example, from 2003 the Queensland Workplace Health and Safety Act 1995 enacted a series of 'tiered' maximum penalties, escalating with the seriousness of the outcome of the contravention of a general duty provision. Thus, where a breach caused multiple deaths, the maximum penalty was $\mathrm{A} \$ 750,000$ for corporations, and $\mathrm{A} \$ 150,000$ or three years imprisonment for individuals; if the breach caused death or grievous bodily harm, A \$375,000 for corporations and A $\$ 75,000$ or two years' imprisonment for natural persons; 
if the breach caused bodily harm, $\mathrm{A} \$ 281,250$ for corporations and $\mathrm{A} \$ 56,250$ or one year's imprisonment for natural persons; and otherwise, $\mathrm{A} \$ 187,500$ for corporations and $\mathrm{A} \$ 37,500$ for natural persons.

Others made provision for higher fines where employers recklessly (or through gross negligence) exposed workers to serious risks. For example, section 32 of the Victorian Occupational Health and Safety Act 2004 created an offence of recklessly placing another person at a workplace in danger of serious harm, with a maximum penalty of $A \$ 1,020,780$ for a corporation and A $\$ 204,156$ or five years' imprisonment for a natural person. From 2008, section 59 of the South Australian Occupational Health, Safety and Welfare Act 1986 created a new offence of recklessly acting in a manner that created a substantial risk of death or serious harm to another person in the workplace, with maximum penalties of A\$1,200,000 for corporations, and $\mathrm{A} \$ 400,000$ or five years' imprisonment for natural persons. Sections 30 to 34 of the Work Safety Act 2008 (ACT) created a series of offences for:

- contraventions of the general duty provisions which resulted in negligent exposure to substantial risk of serious harm

- reckless exposure to substantial risk of serious harm

- negligent exposure to serious harm

- reckless exposure to serious harm.

The Western Australia Act included both approaches. From 2004, section 19A of the Western Australia Occupational Safety and Health Act 1984 created new offences if an employer contravened the employer's general duty in circumstances of gross negligence (maximum fine $\mathrm{A} \$ 500,000$ for a first offence by a corporation and $\mathrm{A} \$ 625,000$ for a subsequent offence; and for an individual 50 per cent of the corporation fine or two years' imprisonment) or resulting in death or serious harm to an employee (maximum fine $\mathrm{A} \$ 400,000$ for a first offence by a corporation and $\mathrm{A} \$ 500,000$ for subsequent offences; and for an individual, 50 per cent of the corporation fine).

Finally, two statutes created offences where the key elements involved both mens rea and a fatality - in a sense provisions strongly resembling industrial manslaughter but in the work health and safety statute. The New South Wales Occupational Health and Safety Act 2000 from 2005 included section 32A, which created an offence where a breach of a general duty provision caused the death of a person to whom a duty is owed and the duty holder was reckless as to the danger of death or serious injury. The maximum penalty for this offence was set at $\mathrm{A} \$ 1,650,000$ for a corporation and $\mathrm{A} \$ 165,000$ or five years' imprisonment for a natural person. Section 82 of the 2007 Northern Territory Act created an offence of intentional breach causing death, with, for a corporation, a minimum penalty of $\mathrm{A} \$ 137,500$ and a maximum penalty of $\mathrm{A} \$ 1,375,000$; and, for a natural person, a minimum penalty of $\mathrm{A} \$ 27,500$ and a maximum of $\mathrm{A} \$ 275,000$ or five years' imprisonment.

To date, these provisions appear to have been little used. This is not altogether surprising because prosecution rates, particularly in the larger jurisdictions (New South Wales, Victoria and Queensland), have been falling, particularly in the past few years, and prosecution rates have never been high in the other jurisdictions. A rare case was the prosecution of Orbit Drilling Pty Ltd under section 32 of the Victorian Act for an incident in 2006, when an untrained 21-year-old was killed while driving a heavily loaded truck down a very steep slope. The truck had not been properly maintained, and the brakes were defective. The company admitted that it had engaged in reckless conduct that had placed an employee in 
danger of serious injury. The company was fined $\mathrm{A} \$ 750,000$, which was upheld on appeal by the Supreme Court of Victoria, Court of Appeal. ${ }^{33}$

\section{Non-pecuniary sanctions}

Another approach to boosting the sanctions available to courts hearing work health and safety prosecutions has been to empower courts with non-pecuniary penalties. The weaknesses of the fine in the context of corporate offending have been well documented. ${ }^{34}$ These include the fact that fines do not usually reflect an organisation's ability to pay, and thus penalise smaller firms and have little impact on large firms; corporations can, at least in some instances, absorb the costs of the fine by passing these on to consumers, workers and/or shareholders; corporations can simply pay a fine without doing anything to improve health and safety; and the fact that it is counterproductive to fine public sector corporations. Consequently, from 2000, some of the Australian work health and safety statutes introduced new corporate sanctions aimed at addressing at least some of these weaknesses, and aiming at rehabilitation, restitution and shaming in addition to the traditional focus on deterrence. The most notable provisions were:

- adverse publicity court orders (New South Wales, Victoria, South Australia, the ACT and the Northern Territory)

- a court order that the offender participate in a work health and safety-related project (New South Wales, Victoria, South Australia)

- an order requiring the defendant to take remedial measures (Commonwealth, New South Wales, the ACT and the Northern Territory) or to undertake training (South Australia and the Northern Territory)

- adjourning the case with/without conviction and requiring the defendant to give an undertaking not to reoffend within two years and to engage a consultant, develop systematic work health and safety management and for this to be monitored by a third party (Victoria and Western Australia).

While it can be argued that these sanctions do address, at least in part, some of the criticisms of the fine, some argue that these non-pecuniary sanctions themselves signal that work health and safety offences are not 'really criminal', because they are not the sorts of sanction that are used for serious criminals within the criminal justice system. Again, these non-pecuniary sanctions have not been used by the courts much.*

\section{The harmonised Work Health and Safety Acts: the current approach}

The approach outlined in the previous section - non-pecuniary penalties and high maximum pecuniary penalties for work health and safety offences, and additional offences where contraventions involve mens rea of some kind and/or place workers or others at high levels of risk - has now been institutionalised through the process of harmonising Australian work health and safety law. In 2010 the Workplace Relations Ministers' Council finalised and adopted a model Work Health and Safety Act, which to date has been enacted by the Commonwealth, New South Wales, Queensland, South Australia, Tasmania, the ACT and the Northern Territory. The recently enacted Work Health and Safety Acts now institutionalise an approach that seeks to assert the criminality of work health and safety offences by imposing high penalties for contravention, particularly where there is recklessness that exposes others to high risk; enables reckless individuals to be imprisoned; and enables courts to impose nonpecuniary sanctions.

\footnotetext{
* There are, however, a number of rare examples. ${ }^{35}$
} 
Sections 30 to 33 of the Work Health and Safety Acts provide for a tiered penalty regime for contraventions of the general duties. A person commits a category 1 offence when the person breaches a general duty by engaging in conduct that exposes an individual to a risk of death or serious injury or illness; and the person is reckless as to that risk. The maximum penalty for a category 1 offence is $\mathrm{A} \$ 3$ million for a corporation; A $\$ 600,000$ and/or five years' imprisonment for an individual conducting a business or undertaking, or an officer of a person conducting a business or undertaking; and A $\$ 300,000$ and/or five years' imprisonment for an offence committed by any other individual.

A person commits a category 2 offence where non-compliance with a general duty exposes an individual to a risk of death or serious injury or illness. The maximum penalty for a category 2 offence is $\mathrm{A} \$ 1.5$ million for a corporation; $\mathrm{A} \$ 300,000$ for an individual conducting a business or undertaking, or an officer of a person conducting a business or undertaking; and A $\$ 150,000$ for an offence committed by any other individual.

All remaining breaches of the general duty provisions are category 3 offences, where the maximum penalties are $\mathrm{A} \$ 500,000, \mathrm{~A} \$ 100,000$ and $\mathrm{A} \$ 50,000$ respectively.

The court can also make orders for non-pecuniary penalties, ${ }^{36}$ which include:

- adverse publicity orders, where the offender is ordered to publicise - or notify a specified person (or class of persons) of - the offence, its consequences, the penalty imposed and any other related matter

- restoration orders, which order the duty holder to take steps within their power to remedy any matter caused by the commission of the offence

- work health and safety project orders, which order the duty holder to undertake a stated project for the general improvement of work health and safety

- release of the duty holder on giving a 'court-ordered WHS undertaking' not to commit further offences, and to observe special conditions

- injunctions to require an offender to cease contravening the Act

- training orders, for one or more workers to undertake a specified course of training.

\section{Conclusions}

In this paper I have outlined the historical processes that have 'decriminalised' the Australian work health and safety statutes. I have argued that this decriminalisation is the result of the way in which work health and safety offences have been differentiated from 'real' crimes of violence in the mainstream criminal law; the reluctance of work health and safety inspectorates to prosecute work health and safety offences; and the relatively low penalties imposed by courts once health and safety issues are individualised and decontextualised when prosecutions are conducted.

I have also documented the Australian public policy debate about industrial manslaughter, a debate that has had minimal legislative effect. Only Australia's smallest jurisdiction, the ACT, enacted provisions in 2002 enabling corporations and senior offices to be prosecuted for the work-related deaths of workers. In all other Australian jurisdictions, prosecutions for gross negligence manslaughter can be brought against corporations and senior officers, but they are very unlikely to succeed against any but the smallest of firms, for the reasons outlined earlier in the paper.

Instead, in the past decade most Australian governments have done three things to bolster the 'criminality' of work health and safety offences: increase the maximum penalties; create new 
offences (with higher levels of penalty) for contraventions of the work health and safety statutes involving recklessness or gross negligence and/or resulting in death; and introducing non-pecuniary sanctions. This policy response has now been institutionalised through the process of harmonising Australian work health and safety law in the newly enacted Work Health and Safety Acts in the Commonwealth, New South Wales, Queensland, South Australia, Tasmania, the ACT and the Northern Territory. At best, however, these reforms have only partly addressed the factors leading to the perception that work health and safety offences are not 'real' crimes - the sanctions for contraventions are significant but the ideological baggage of the ambiguity and conventionalisation of work health and safety crime still hold sway.

Ironically, however, the provisions of the model Work Health and Safety Act contemplate that gross negligence manslaughter be used for work-related fatalities. The original recommendation for the introduction of a category 1 offence specified that the offence should arise when 'there was serious harm to any person (fatality or serious injury) to whom a duty is owed or a high risk of such harm; and the duty holder has been reckless or grossly negligent'. ${ }^{37}$ This recommendation was modified by the Workplace Relations Ministers' Council to 'an offence of recklessly endangering a person to risk of death or serious injury at a workplace ${ }^{38}$ - that is, as the description of the category 1 offence in the previous section shows, 'gross negligence' and a 'fatality' were removed from the elements of the offence, because, so I understand, otherwise the offence would overlap with the key elements in the crime of gross negligence manslaughter. In other words, the Work Health and Safety Acts leave 'space' for the crime of industrial manslaughter prosecutions, but the debilitating weaknesses in the current law of manslaughter for corporations and for senior officers outlined in this paper - remain in place everywhere but in the ACT.

It seems safe to say that the debate about gross negligence manslaughter is off the policy agenda - at least in the near future. The manslaughter debate is unlikely to resurface in the next five to 10 years, largely because the political party prepared to consider reform of manslaughter law, the Australian Labor Party at state and territory level, has largely lost favour with the electorate. Sadly, only an incident resulting in mass fatalities - similar to the Westray tragedy 20 years ago - is likely to revive the work-related manslaughter debate in Australia.

\section{References}

1. Carson W G. The conventionalisation of early factory crime. International Journal of the Sociology of Law 1979; 7 (1): 37-60.

2. Carson W G. The institutionalization of ambiguity: early British factory acts. In: Geis G and Stotland E (eds). White collar crime: theory and research. London: Sage, 1979.

3. Carson W G. The conventionalisation of early factory crime. International Journal of the Sociology of Law 1979; 7 (1): 38.

4. Tombs S and Whyte D. Safety crimes. Cullompton: Willan Publishing, 2007: 117-118.

5. Chief Inspector. Annual report. Brisbane, 1897: 6.

6. Prior P F. Enforcement: an inspectorates' view. In: Creighton W B and Gunningham N (eds). The industrial relations of occupational health and safety. Sydney: Croom Helm, 1985: 54-55.

7. Productivity Commission. Performance benchmarking of Australian business regulation: occupational health and safety. Research Report. Canberra: Productivity Commission, 2010: 115, Table 5.9.

8. Safe Work Australia. Comparative performance monitoring report: comparison of work 
health and safety and workers' compensation schemes in Australia and New Zealand. 14th Edition. Canberra: Safe Work Australia, 2012: 15.

9. Johnstone R. Occupational health and safety, courts and crime: the legal construction of occupational health and safety offences in Victoria. Sydney: The Federation Press, 2003.

10. Johnstone R. Occupational health and safety, courts and crime: the legal construction of occupational health and safety offences in Victoria. Sydney: The Federation Press, 2003: 93.

11. Johnstone R. Occupational health and safety, courts and crime: the legal construction of occupational health and safety offences in Victoria. Sydney: The Federation Press, 2003: 206-211.

12. Johnstone R. Occupational health and safety, courts and crime: the legal construction of occupational health and safety offences in Victoria. Sydney: The Federation Press, 2003: 211-238.

13. Johnstone R. Occupational health and safety, courts and crime: the legal construction of occupational health and safety offences in Victoria. Sydney: The Federation Press, 2003: 288-94.

14. Johnstone R. Occupational health and safety, courts and crime: the legal construction of occupational health and safety offences in Victoria. Sydney: The Federation Press, 2003: 276-284.

15. Australian Government. National Review into Model Occupational Health and Safety Laws. Second report to the Workplace Relations Ministers' Council. Canberra:

Commonwealth of Australia, 2009: 257-259. www.worksafe.nt.gov.au/

Publications/Reports/NationalReviewintoModelOHSLawssecondreport.pdf. Viewed 13 November 2013.

16. Johnstone $\mathrm{R}$ and Tooma $\mathrm{M}$. Work health and safety regulation: the model Act. Sydney: The Federation Press, 2012: 102-104.

17. Johnstone $\mathrm{R}$ and Tooma M. Work health and safety regulation: the model Act. Sydney: The Federation Press, 2012.

18. Johnstone R and King M. A responsive sanction to promote systematic compliance?: enforceable undertakings in occupational health and safety regulation. Australian Journal of Labour Law 2008; 21: 280.

19. $R v$ Lavender [2005] HCA 37; endorsing Nydam $v R$ [1977] VR 430 at 445.

20. $R v$ Smith (Unreported, District Court of New South Wales, Criminal Jurisdiction, Newcastle, Judge English, 2008/5549, 6 November 2008); R v Thurkell (Unreported, District Court of New South Wales, Criminal Jurisdiction, Newcastle, Judge English, 2008/5550, 6 November 2008).

21. Presidential Security Services of Australia Pty Ltd v Brilley [2008] NSWCA 204 at [10], referring to R $v$ HM Coroner for East Kent; Ex parte Spooner (1989) 88 Cr App R 10; PひO European Ferries (Dover) Ltd (1991) 93 Cr App R 72; Attorney-General's Reference (No 2 of 1999) [2000] QB 796; Transco plc $v$ Her Majesty's Advocate [2005]. BCC 296; R v Murray Wright Ltd [1970] NZLR 476.

22. $R v$ Denbo Pty Ltd (Supreme Court of Victoria, Hampel J, 2 June 1994).

23. Bronnit $\mathrm{S}$ and McSherry B. Principles of criminal law. Sydney: LBC Information Services, 2001: 157.

24. Fisse B. Individual and corporate criminal responsibility and sanctions against corporations. In: Johnstone $\mathrm{R}$ (ed). Occupational health and safety prosecutions in Australia: overview and issues. Melbourne: Centre for Employment and Labour Relations Law, The University of Melbourne, 1994: 100-101.

25. $R v$ Adomako [1995] 1 AC 171. 
26. Centre for Corporate Accountability. Statistics on convictions in England and Wales, 2008: at para 3.27. www.corporateaccountability.org.uk/manslaughter/cases/ convictions.htm. Viewed 13 October 2011.

27. Centre for Corporate Accountability. Statistics on convictions in England and Wales, 2008: at para 3.31. www.corporateaccountability.org.uk/manslaughter/cases/ convictions.htm. Viewed 13 October 2011.

28. Haines F and Hall A. The law and order debate in occupational health and safety. Journal of Occupational Health and Safety: Australia and New Zealand 2004; 20 (3): 263-273.

29. Carson W G and Johnstone R S. The dupes of hazard: occupational health and safety and the Victorian sanctions debate. Australian and New Zealand Journal of Sociology 1990; 26 (1): 126.

30. Appleby M. Accounting for corporate killing - Time for change. Occupational Health Review 2003; 14 (2): 9-39.

31. Australian Government. National Review into Model Occupational Health and Safety Laws. First report to the Workplace Relations Ministers' Council. Canberra: Commonwealth of Australia, 2008: 93. www.worksafe.nt.gov.au/Publications/Reports/ NationalReviewintoModelOHSLawsFirstreport.pdf. Viewed 13 November 2013.

32. Comcare $v$ Commonwealth of Australia (2007) 163 FCR 207 (per Madgwick J at para 120), adopted by Collier J in Comcare $v$ The Commonwealth of Australia [2010] FCA 133: paras [36]-[37], and in Comcare v Subsee Explorer Pty Ltd [2011] FCA 837. For other cases in which the relevant sentencing principles are helpfully discussed and applied, see DPP v Amcor Packaging Australia Pty Ltd [2005] VSCA 219; (2005) 11 VR 557; Comcare v Australian Postal Corporation [2011] FCA 530 and Inspector Madeline Christensen v Universal Cranes Pty Ltd [2011] NSWIRComm 98.

33. Orbit Drilling Pty Ltd $v$ The Queen [2012] VSCA 82.

34. Gunningham N and Johnstone R. Systems and sanctions: regulating workplace safety. Oxford: Oxford University Press, 1999: 256-259; Tombs S and Whyte D. Safety crimes. Cullompton: Willan Publishing, 2007: Chapter 8.

35. Inspector Covi v New South Wales Police Service [2003] NSWCIMC 15; Inspector Franke v Eurodalla Shire Council [2003] NSWCIMC 33; Inspector Constable v National Parks and Wildife Services (NSW) [2003] NSWCIMC 64; Inspector Ankucic v Department of Education and Training (NSW) [2003] NSWCIMC 79; Inspector Przibilla $v$ Department of Education and Training (NSW) [2004] NSWCIMC 4.

36. Work Health and Safety Acts 2011, Part 13, Division 2.

37. Australian Government. National Review into Model Occupational Health and Safety Laws. First report to the Workplace Relations Ministers' Council. Canberra: Commonwealth of Australia, 2008: 108, Table 11. www.worksafe.nt.gov.au/ Publications/Reports/NationalReviewintoModelOHSLawsFirstreport.pdf. Viewed 13 November 2013.

38. Workplace Relations Ministers' Council. WRMC response to recommendations of the National Review into Model OHS Laws. 2009: 13. www.safeworkaustralia.gov.au/sites/ SWA/about/Publications/Documents/515/WRMC81outcomesMay09.pdf. Viewed 13 November 2013. 